\title{
Epidemiological profile of west center cornea donors
}

\author{
Perfil epidemiológico dos doadores \\ de córnea do Estado de Goiás
}

Rodrigo Egidio da Silva', Rodrigo Macioca Morato², Roberto Tarley Stival Veneziano ${ }^{2}$, Francisco Wellington Rodrigues ${ }^{1}$

\begin{abstract}
Objective: Describe the epidemiological profile of cornea donors in the state of Goiás. Methods: We used a random sample of 793 records calculated by the formula of Leslie Kish (Epi Info 7) taking into account a total of 3,093 records from January 2006 to August 2015. The data was analyzed using the Statistical Package for Social Sciences (SPSS) and the results were described using proportions, central tendency and dispersion measures. Comparisons between categorical variables were made using the chi-square test with $5 \%$ significance level. Results: The mean age was 37.33 years, and the majority was male (81.21\%). The most frequent cause of death was traumatic brain injury (34.04\%) followed by acute myocardial infarction (14.12\%). Among the first five years, the time between death and enucleation was $4.7 \pm 1.7$ hours while that in recent years was $4.9 \pm 1.6$ hours. Time between death and preservation was $13 \pm 4.6$ hours in the period 2006 to 2010 and $11.4 \pm 4.7$ hours in 2011 to 2015 ( $p<0.001)$. Conclusion: We could conclude that age was statistically significant in the younger population, with an increase of the same in the last 10 years. We need to create and implement educational campaigns to raise awareness of this issue in the general population, and thus reduce the incidence of the younger age group. We also need to keep updated all professionals working in this area, the approach staff, cornea collection team, nurses and doctors to better capture and preserve donor corneas.
\end{abstract}

Keywords: Cornea; Epidemiology; Health profile; Tissue donors/statistics \& numerical data

\section{Resumo}

Objetivo: Traçar o perfil epidemiológico dos doadores de córnea do Estado de Goiás. Métodos: Foi utilizada amostra probabilística de 793 prontuários calculada pela fórmula de Leslie Kish (Epi Info 7), levando em consideração um n total de 3.093 prontuários no período de janeiro de 2006 a agosto de 2015. Os dados foram analisados utilizando o programa Statistical Package for Social Science (SPSS) e os resultados foram descritos por meio de proporções, medidas de tendência central e dispersão. As comparações entre variáveis categóricas foram feitas através do teste Qui-Quadrado com nível de significância de 5\%. Resultados: A média de idade foi de 37,33 anos, sendo que a maioria foi do sexo masculino (81,21\%). A causa mortis mais frequente foi traumatismo crânio encefálico $(34,04 \%)$ seguido pelo infarto agudo do miocárdio (14,12\%). Entre os cinco primeiro anos, o tempo entre o óbito e a enucleação foi

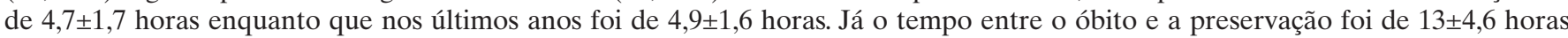
no período de 2006 a 2010 e de 11,4 $\pm 4,7$ horas no período de 2011 a 2015 (p<0,001). Conclusão: Conclui-se que o fator idade foi estatisticamente significante na população mais jovem com aumento nos últimos 10 anos. São necessárias campanhas sócia educativas para a conscientização da população geral e com isso, reduzir a incidência da faixa etária mais jovem, assim como a necessidade de manter atualizados todos os profissionais que atuam nessa área, desde a equipe de abordagem, de colheita, de enfermeiros e médicos para melhor captação e preservação de córneas para transplantação.

Descritores: Córnea; Epidemiologia; Perfil de saúde; Doadores de tecidos/estatística \& dados numéricos

\footnotetext{
${ }^{1}$ Pontifícia Universidade Católica de Goiás - Goiânia, GO, Brazil.

2 Medicine School, Pontifícia Universidade Católica de Goiás, Goiânia, GO, Brazil.

Study carried out at Pontifícia Universidade Católica de Goiânia, Goiânia, GO, Brazil.

The authors declare no conflicts of interests.

Received for publication 18/03/2016 - Accepted for publication 27/06/2016.
} 


\section{INTRODUCTION}

C orneal transplant is currently the most accomplished transplant in the world, with the best prognosis compared to the lifetime of the graft due to lower rejection rate compared to other transplants. It happens because the cornea has no cascularization ${ }^{(1)}$. The first cornea transplant in Brazil was carried out in 1958 by Hilton Rocha at Hospital das Clínicas of Universidade Federal de Minas Gerais ${ }^{(2)}$. Since then, it is the most accomplished transplant throughout the national territory ${ }^{(3)}$.

Although the rate of cornea transplant is decreasing since 2012, and in 2014 the fall was $5.2 \%$ compared to the previous year, the number of people waiting is decreasing year after year ${ }^{(3)}$. This fact can be explained by a decreasing demand of donations, by the emergence of new technologies that can reduce transplant indication, or by the patient not having access to the transplant service ${ }^{(3)}$.

In 2014, 13,036 corneal transplants were performed in Brazil, equivalent to 68.3 transplants per million inhabitants. In absolute numbers, the state of São Paulo held most transplants, and Goiás was the sixth state. However, when considering transplants per million inhabitants, Goiás is the second state in number of transplants, and São Paulo is the fourth ${ }^{(3)}$.

Fundação Banco de Olhos de Goiás (FUBOG) is a humanitarian and non-profit charity established, managed and maintained by the Lions Club of Grande Goiânia. It has already attended more than 1,590,000 people since its inauguration, with more than 8,000 corneal transplants in 30 years $^{(4)}$. Although FUBOG works since 1983, it was only in 2000 with Ordinance 902/ 2000 of the Ministry of health that it was regulated as a Bank ${ }^{(5)}$.

Considering the lack of studies in the area and the specificity of the region, the present study aims to analyse the epidemiological profile of the cornea donors in the state of Goiás in the last 10 years, and use the data obtained to create specific tools to enhance the uptake and distribution of corneas and plan possible educational campaigns for the general population.

\section{Methods}

It is a cross-sectional observational study. The review of the medical records from January 2006 to August 2015 of corneadonor patients of Fundação Banco de Olhos de Goiás was carried out. This study was approved by the Ethics and Research Committee of Pontifícia Universidade Católica de Goiás.

The data was obtained by data collection from the medical records of cornea donors obtained by the FUBOG team. The variables studied were: age, gender, cause of death; time of patient's death; enucleation time, and time of preservation of the cornea.
The inclusion criteria was the medical records of cornea donors from January 2006 to August 2015 with all the data surveyed in the correct and legible form. Those who were outside of this period and who did not have all the data filled in were excluded.

The probabilistic sample of 793 medical records was used and calculated by the formula of Leslie Kish (Epi Info 7), considering a total of 3,093 medical records from January 2006 to August 2015, with a confidence interval (CI) of $95 \%$ and a sampling error of $3 \%$. The selection of the medical records was made by systematic random sampling, in which each year had an amount of medical records analyzed in proportion to the total amount.

Data was entered and manipulated in Excel for further data processing using the program Statistical Package for Social Science (SPSS) of Windows (version 21.0).

The results were described using proportions, central tendency and dispersion measures. Comparisons between categorical variables were made with the Chi-squared test, with a significance level of $5 \%$.

\section{ResulTS}

Of the 793 medical records reviewed, 453 were from the period from 2006 to 2010, and 340 were from the period from 2011 to 2015. In the period from 2006 to 2015, the year with the highest number of uptaking was 2006, and the year with the lower uptake was 2012 (Graph 1).

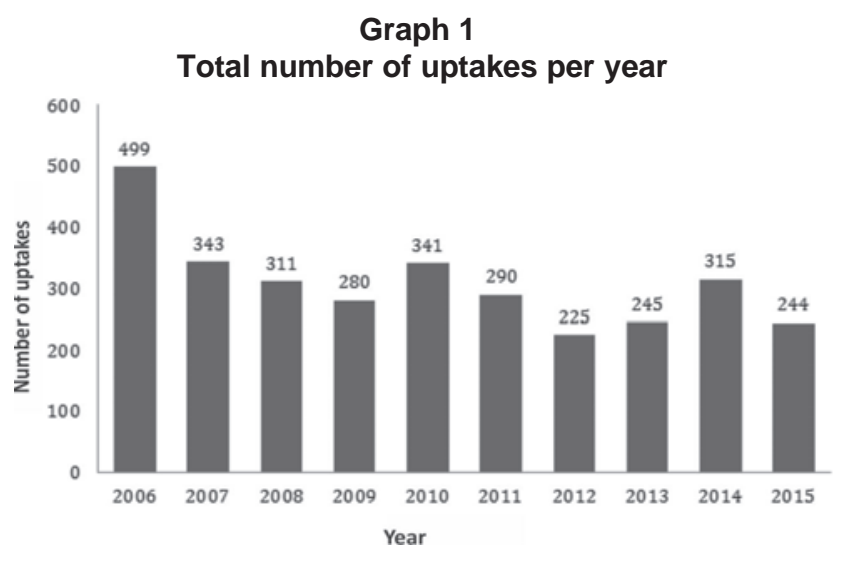

Age

Throughout the period of 10 years, the average age was of 37.33 years. But between 2006-2010 it was $39.01 \pm 17.9$ years, and between 2011-2015 it was 35.0 \pm 16.2 years (Table 1 ). The oldest age of the sample was 88 years old, and the youngest was 1 year, with an average of 34 years.

Table 1

Comparison of the parameters of the variables age, enucleation time and time of preservation

\begin{tabular}{lccccl}
\hline Characteristics & \multicolumn{2}{c}{$\mathbf{2 0 0 6}$ to $2010(\mathbf{n}=\mathbf{4 5 4})$} & \multicolumn{2}{c}{$\mathbf{2 0 1 1}$ to $2015(\mathbf{n = 3 4 0 )}$} & P-value \\
& Mean \pm SD & Mean $(\mathbf{I C 9 5} \%)$ & Mean \pm SD & Mean (IC95\%) & \\
\hline Idade & $39.01 \pm 17.9$ & $36.0(37.4-40.7)$ & $35.0 \pm 16.2$ & $32.0(33.3-36.7)$ & $0.002^{*}$ \\
T1 & $4.7 \pm 1,7$ & $5.0(4.6-4.9)$ & $4.9 \pm 1.6$ & $5.0(4.7-5.0)$ & 0.062 \\
T2 & $13.5 \pm 4.6$ & $13.3(13.0-13.9)$ & $11.4 \pm 4.7$ & $10.2(10,9-11.9)$ & $<0.001 *$ \\
Dif.(T2-T1) & $8.6 \pm 4.5$ & $8.2(8.2-9.0)$ & $6.5 \pm 4.3$ & $5.0(6.0-6.9)$ & $<0.001^{*}$ \\
\hline
\end{tabular}

* Significativo; $\mathrm{T} 1=$ tempo de óbito até enucleação T2= tempo do óbito até preservação da córnea. 


\section{Gender}

Regarding gender-related distribution, the sample showed that $81.21 \%$ of cornea uptaken were from men. However, there was no significant variation regarding the gender of the donors between the periods (Table 2).

Table 2

Distribution of the variable gender

\begin{tabular}{|c|c|c|c|c|c|}
\hline \multirow[t]{2}{*}{ Characteristics } & \multicolumn{2}{|c|}{$\begin{array}{c}2006 \text { to } 2010 \\
(n=454)\end{array}$} & \multicolumn{2}{|c|}{$\begin{array}{c}2011 \text { to } 2015 \\
(n=340)\end{array}$} & \multirow[t]{2}{*}{ p-Value } \\
\hline & $\mathbf{f}$ & $\%$ & $\mathbf{f}$ & $\%$ & \\
\hline \multicolumn{6}{|l|}{ Gender } \\
\hline Male & 372 & 81.9 & 275 & 80.9 & 0.713 \\
\hline Female & 82 & 18.1 & 65 & 19.1 & \\
\hline Total & 454 & 100.0 & 340 & 100.0 & \\
\hline
\end{tabular}

\section{Cause of Death}

The causes of death were grouped into nine groups, namely: Acute myocardial infarction (AMI); Shot by gun (SBG); Traumatic brain injury (TBI); shot by firearms (SBF); Polytrauma; Cerebrovascular accident (CVA); Neoplasia; Suicide and others. The most frequent cause of death in 10 years was TBI with 270 deaths (34.04\%), followed by AMI with 112 (14.12\%), Polytrauma with 105 (13.24\%), SBF with 100 (12.61\%), CVA with 42 (5.29\%), SBG with $25(3.15 \%)$, Suicide with 17 (2.14\%), and Neoplasia with $10(1.26 \%)$. The other causes of death accounted for $14.12 \%$ of the total, comprising 112 cases. In the first five years, the AMI represented $22.95 \%$ of the total causes of death in the period. However, in the last five years, AMI represented $2.3 \%$ of the total of the period. (Graph 2).

\section{Graph 2 \\ Distribution of the variables cause of death and time}

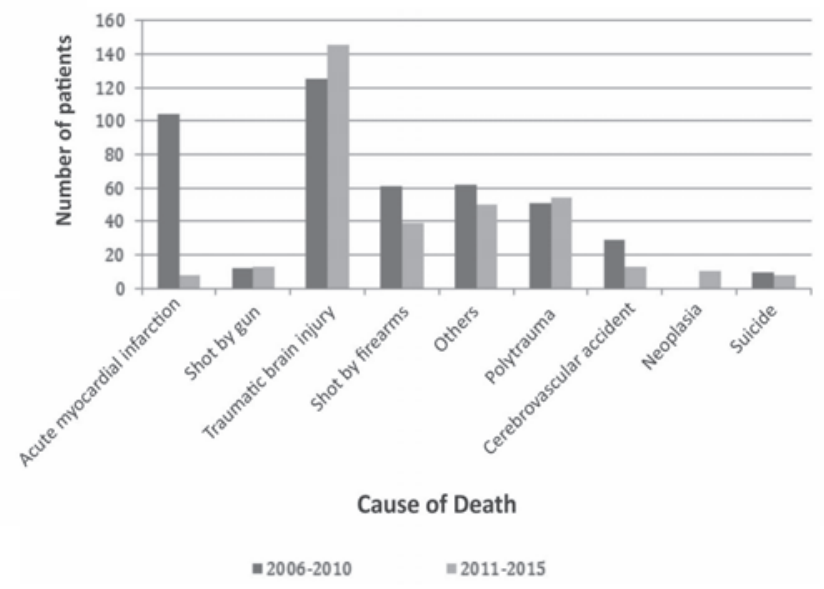

Time of obit/enucleation and death/preservation

During the first five years, the time between death and enucleation was $4.7 \pm 1.7$ hours, whereas in recent years it was $4.9 \pm 1.6$ hours.

The time between death and preservation was $13 \pm 4.6$ hours in the period from 2006-2010, and $11.4 \pm 4.7$ hours in the period from 2011-2015 $(\mathrm{p}<0.001)$.
The time between enucleation and preservation calculated as the difference between the two times mentioned above was $8.6 \pm 4.5$ hours in the first five years and $6.5 \pm 4.3$ hours in the last five years. When comparing both periods, there was a statistically significant variation (Table 1 ).

\section{Discussion}

Our study showed a gradual decrease in the number of cornea crops over the years studied, going from 1774 in the period from 2006 to 2010 to 1319 in the period from 2011 to 2014. From the year 2007, there was a change in the evaluation of donor candidates, which led to a more careful donation, the use of laboratory techniques to demonstrate the corneal quality, and possible disposal of donor corneas with a previous history of eye surgery. This result matches that of a study conducted at the eye bank of Hospital Sao Paulo ${ }^{(6)}$. However, the two studies cannot be correlated in a transverse way, since the population reality is different in the two states ${ }^{(3)}$.

Another important point of the study is the increased number of deaths by external causes, such as car accidents during the analysis period, especially in the younger age groups, being most of them males aged between 18 and 33 years. This may be a bias of our sample, knowing that most of the donors are from the forensic medicine institute (Instituto Médico Legal - IML), where deaths by the external cause are forwarded. However, we can explain this number of external causes with a gradual increase of deaths by car accidents in Goiás since $2006^{(7)}$, with a higher incidence in males ${ }^{(7,8)}$.

Analyzing donors by gender, there was a predominance of male donors, which is in agreement with other studies ${ }^{(6,9,10)}$. However, our sample was less accurate because other studies had a more homogeneous sample when comparing genders ${ }^{(6,9,10)}$. This fact leads us to correlate the most important cause of death - external causes - to males due to greater risk of exposure to environmental factors associated to their work or social activity.

The higher prevalence of male donors is in accordance with the literature, and presumably with the fact that men die younger of cardiovascular disease and external causes ${ }^{(6,9,11,12)}$. This fact is relevant due to the high economic impact that this specific population represents to the economy of a nation, leading to a loss of immeasurable value to society ${ }^{(13)}$.

The average age of donors was 37.3 years, being lower than that found in other studies ${ }^{(6,9,10,14-16)}$. We believe that it reflects a trend of large urban centers where youngsters are progressively more related to the various types of deaths associated with external causes, from crime to car accidents. The literature shows a number of studies demonstrating the relation of deaths by external causes in younger ages ${ }^{(11,12)}$.

This study shows that the time between death and enucleation showed an increased period from 2011 to 2015 when compared to the period from 2006 to 2010 . However, the time of both periods was higher than the one in other studies ${ }^{(9,17)}$. Although higher, this value is within the limit of six hours between death and enucleation ${ }^{(6,18-20)}$, whereas another study shows that enucleation may be placed within 24 hours if the body is cooled ${ }^{(21)}$. In our study the cornea was preserved for a maximum of 14 days of preservation, which was also found in other 
studies $^{(1,18,21,22)}$. We also noticed a significant reduction in the time between enucleation and preservation, which may mean an improvement in the uptake department by qualification and optimization of the staff after training courses. Even if this value is below the one shown in other studies ${ }^{(6)}$, it is extremely important to the team as a motivating factor for the technical improvement.

The most frequent causes of death during these ten years were TBI, followed by AMI, Polytrauma, SBF, CVA, SBG, Suicide, Neoplasia. This etiological distribution demonstrates the importance of deaths by external causes, more frequent in another study and followed by circulatory diseases ${ }^{(9)}$. This data differs from others found in the literature, in which cardiovascular diseases are predominant as causes of death of the donors ${ }^{(1,6,10)}$. Maybe this divergence is due to the place where the uptakes are held. When carried out in forensic medicine institutes or centers dedicated to trauma, the predominant cause of death is external, as shown in the study conducted in Piaui ${ }^{(9)}$.

The data showed a reduction of deaths by natural causes as AMI and CVA when we compare the period from 2006 to 2010 with the period from 2011 to 2015 . We believe that this reduction is related to the fact that by the year 2009 FUBOG was responsible for the uptake of all corneas from the Brazilian Coroner Service (SVO - Serviço de Verificação de Óbitos) in Goiânia, to where deaths that are not by external causes and whose reason needs to be found out are forwarded. Since 2010 the uptakes for that service became the responsibility of other institution.

Uptakes from deaths by neoplasia represent a small part of the total. Over the years, the quality of the tissue changes, as pointed out in the literature by Farias ${ }^{(23)}$ and Pantaleão ${ }^{(16)}$. These authors show that only the tissue analysis makes it possible to rule out potential donors not only due to age ${ }^{(14,16,23,24)}$. Sometimes this small number of donors is justified by the specific type of the collection center of donor corneas (IML), and thus a bias of our sample may be demonstrated.

A study was conducted with doctors and scholars who were questioned about the procedure of donation and the corneal transplant. The lack of basic information by the professional, such as the time of the procedure for the collection of the cornea and the appearance of the donor after the collection of the corneas, was crucial to approach or not the family to obtain consent for the collection. The lack of information generated fear in the professional who chose not to approach the possibility of transplant with the family ${ }^{(23)}$. Another study showed a greater association between a lower level of education and the authorization for donation. Most of the donations were from public hospitals, or in conditions associated to low income, shot by firearms (SBF) and shot by gun $(\mathrm{SBG})^{(22)}$. Again, we found aspects substantiating that the lack of information can reduce the approach for consent and the subsequent donation, making it possible to infer about the potential value of well conducted awareness campaigns.

\section{ConCLUSION}

We concluded that the gradual increase of donors in the young people in the period studied can be associated to external causes and lack of information by the health agents in relation to the collection procedure and cornea transplant, with the number of uptake of cornea donor being a direct influencer. Therefore, the need for investment in information and training of professionals, from the approach staff to the collection team and more qualified specialists such as nurses and doctors, is of utmost importance for the increased uptake. The planning of educational policies and preventive measures on traffic medicine can reduce the incidence of external causes of deaths in the young people, being the direct consequence of it the high attenuation factor of socio economic impact on the general population.

Finally, we must highlight the importance of the dissemination of cornea donation in the social media so that the population is aware of the importance and benefits, leading to an improvement on the socio economic level of a country.

\section{ReFERENCES}

1. Sano RY, Sano FT, Dantas MCN, Lui ACF, Sano ME, Neto AL. Análise das córneas do Banco de Olhos da Santa Casa de São Paulo utilizadas em transplantes. Arq Bras Oftalmol. 2010; 73(3):254-8

2. Universidade homenageia ex-alunos de destaque. Universidade Federal de Minas Gerais. 2003. Boletim n.1409, Ano 29. [Internet]. [citado 201511 de Maio 11]. Disponível em: http://www.ufmg.br/ boletim/bol1409/quinta.shtml.

3. Dimensionamento dos Transplantes no Brasil e em cada estado. Registro Brasileiro de Transplantes. 2015;20(4). [Internet]. [citado 2015 Maio 11 ]. Disponível em http://www.abto.org.br/abtov03/ Upload/file/RBT/2014/rbt2014-lib.pdf.

4. Fundação Banco de olhos de Goiás. Histórico [Internet]. Goiânia, Brasil; 2013. [citado 2015 Maio 11]. Disponível em http:// www.fubog.org/historico.html.

5. Brasil. Ministério da Saúde. Portaria ${ }^{\circ}$ 902/GM de 16 de agosto de 2000. Que regulamenta, no âmbito do Sistema Único de Saúde, o funcionamento e cadastramento de Bancos de Olhos. Diário Oficial da União 17 Ago 2000.

6. Adán CB, Diniz AR, Perlatto D, Hirai FE, Sato EH . Dez anos de doação de córneas no Banco de Olhos do Hospital São Paulo: perfil dos doadores de 1996 a 2005. Arq Bras Oftalmol. 2008; 71(2):176-81.

7. Brasil. Ministério da Saúde. DATASUS. Informações de Saúde. Mortalidade, 2016 [Internet]. [citado 2016 Mar 10]. Disponível em: http://tabnet.datasus.gov.br/cgi/tabcgi.exe?sim/cnv/ ext10go.def

8. Caixeta CR, Minamisava R, Oliveira LM, Brasil VV. Morbidade por acidentes de transporte entre jovens de Goiânia, Goiás. Ciênc Saúde Coletiva. 2010; 15(4):2075-84.

9. Santos NC, Bezerra VL, Melo EC. Características das doações de córnea no estado do Piauí. Rev Bras Oftalmol. 2014; 73(6):351-7.

10. Shiratori CN, Hirai FE, Sato EH. Características dos doadores de córneas do Banco de Olhos de Cascavel: impacto do exame antiHBc para hepatite B. Arq Bras Oftalmol. 2011; 74(1):17-20.

11. Gonsaga RA, Rimoli CF, Pires E:A, Zogheib FS, Fujino MV, Cunha MB. Avaliação da mortalidade por causas externas. Rev Col Bras Cir. 2012; 39(4):263-7.

12. Matos KF, Martins CB. Perfil epidemiológico da mortalidade por causas externas em crianças, adolescentes e jovens em CuiabáMT. Epidemiol Serv Saúde (Brasília). 2012; 21(1):43-53.

13. dos Santos MF, Kassouf AL. Estudos econômicos das causas da criminalidade no Brasil: evidências e controvérsias. EconomiA, Brasília (DF). 2008; 9(2):343-72. 
14. Farias RJ, Kubokawa KM, Schirmer M, Sousa LB. Avaliação de córneas doadoras em lâmpada de fenda e microscopia especular durante o período de armazenamento. Arq Bras Oftalmol. 2007;70(1):79-83.

15. Eye Bank Association of America. Medical Standards. Washington, DC: Eye Bank Association of America; 1993.

16. Pantaleão GR, Zapparolli M, Guedes GB, Dimartini Jr WM, Vidal CC, Wasilewski D, Moreira H. Avaliação da qualidade das córneas doadoras em relação à idade do doador e causa do óbito. Arq Bras Oftalmol. 2009; 72(5): 631-5.

17. Hirai FE, Adán $\mathrm{CB}$, Sato $\mathrm{EH}$. Fatores associados à qualidade da córnea doada pelo Banco de Olhos do Hospital São Paulo. Arq Bras Oftalmol. 2009; 72(1):57-61.

18. Bonfadini G, Roisman V, Prinz R, Sarlo R, Rocha E, Campos M. Doação e fila de transplante de córnea no Estado do Rio de Janeiro. Rev Bras Oftalmol. 2014; 73(4):237-42.

19. Marcomini LA, Sobral RM, Seixas GO, Sousa SJ. Seleção de córneas para transplantes. Rev Bras Oftalmol. 2011; 70(6):430-6.

20. Zantut F, Holzchuh R, Boni RC, Mackus EC, Zantut PR, Nakano $\mathrm{C}$, et al. Análise da qualidade das córneas doadas e do intervalo entre óbito, enucleação e preservação após a implantação de novas normas técnicas e sanitárias em Banco de Olhos Universitário. Arq Bras Oftalmol. 2012; 75(6): 398-401.
21. Torres IB, Araujo MS, Benites MF, Moreira H .Comparação entre potenciais e efetivos doadores de córnea no Hospital universitário Evangélico de Curitiba. J Bras Transpl. 2006; 9: 615-9.

22. Paz AC, Ribeiro PC, Mascarenhas MD, Silva MV. Caracterização dos doadores de órgãos e tecidos para transplante do Estado do Piauí, de 2000 a 2009. Enferm Foco. 2011; 2(2):124-7.

23. Farias RJ, de Sousa LB. Impacto do marketing dos processos de divulgação nas doações de córneas a um banco de tecidos oculares humanos e avaliação do perfil socioeconômico de seus doadores. Arq Bras Oftalmol. 2008; 71(1): 28-33.

24. Benites MF, Araujo MS, Torres IB, Canto GF, Cebrian R, Moreira H. Mudanças no padrão de conduta do transplante de córnea após campanha informativa. Rev Bras Oftalmol. 2008; 67(4):172-6.

\section{Corresponding author:}

Rodrigo Egidio da Silva

Av. Americano do Brasil, n²60, Goiânia (GO), Brazil, 74180-110

E-mail: rodrigoegidio@ver.med.br 